\title{
Okul Öncesi Dönem Çocuklarının Okul Hazırbulunuşluklarının Yordayıcısı Olarak Sosyal Bağımsızlık
}

DOI: $10.26466 /$ opus.681864

\author{
Filiz Erbay* - Neslihan Durmuşoğlu Saltalı ** \\ * Doç. Dr., Yakın Doğu Üniversitesi, Eğitim Fakültesi, Lefoşe/KKTC \\ E-Posta: filizerbay42@gmail.com \\ ORCID: 0000-0002-9766-8570 \\ ** Doç. Dr., Ordu Üniversitesi, Eğitim Fakültesi, Ordu/Türkiye \\ E-Posta: ndsaltali@gmail.com \\ ORCID: $\underline{0000-0002-6912-7080}$
}

$\ddot{O} z$

Çocuğun eğitimi sürecinde okul ortamının eğitimsel gereklerini yerine getirebilmesi ve öğretimsel faaliyetleri başarılı bir biçimde sürdürebilmesinde önemli faktörlerden birisi çocuğun okula hazırbulunuşluk durumudur. Bu anlamda çocuğun okula hazırbulunuşluk durumunun ilişkili olduğu faktörlerin bilimsel araştırmalarla ortaya çıkarılmasının önemli olduğu düşünülmektedir. Bu çalışmada da bu noktadan hareketle okul öncesi eğitime devam eden çocukların sosyal bağımsızlık becerilerinin okul hazırbulunuşluklarını yordama durumunun incelenmesi amaçlanmıştır. Araştırma nicel araştırma desenlerinden ilişkisel tarama modelinde yürütülmüştür. Araştırmanın örneklemini Konya ilinde Milli Ĕ̆itim Bakanlığı'na bağhl ilköğretim okullarının anasınıflarına devam eden 279 okul öncesi dönem çocuğu oluşturmuştur. Araştırmada çocukların sosyal bağımsızlık becerisinin ölçülmesinde Anaokulu ve Anasınıfı Davranış Ölçeği'nin sosyal bağımsızlık alt boyutu, okula hazırbulunuşluk düzeylerinin belirlenmesinde Altı Yaş Çocukları için Duygusal ve Davranışsal Dereceleme Ölçeği'nin okula hazırbulunuşluk alt boyutu kullanılmıştır. Araştırmanın verilerinin çözümlenmesinde Pearson momentler çarpımı korelasyon katsayısı analizi ve basit doğrusal regresyon analizi yöntemleri kullanılmıştır. Araştırma sonuçları okul öncesi dönemde çocukların sosyal bağımsızlık becerilerinin okula hazırbulunuşluk durumlarının anlamlı açıklayıcısı olduğunu göstermiştir

Anahtar Kelimeler: Sosyal bağımsızlık, okula hazırbulunuşluk, okul öncesi eğitim 


\title{
Social Independence As A Predictor Of School Readiness Of Preschool Children
}

\begin{abstract}
School readiness is one of the important factors in the child's ability to fulfill the educational requirements of the school environment and to maintain educational activities successfully. In this sense, it is considered that it is important to reveal the factors associated with school readiness. In this study, it is aimed to examine the social independence skills of preschoolers as predictor their school readiness from this point. The research was carried out in the relational screening model, which is one of the quantitative research patterns. The sample of the study consisted of 279 preschool children attending kindergartens of primary schools affiliated to the Ministry of National Education in Konya. In the research, Kindergarten and Kindergarten Behavior Scale social independence subscale was used to measure children's social independence skills, and the school readiness sub-dimension of the Emotional and Behavioral Rating Scale for Six-Year-Old Children was used to determine the levels of school readiness. Pearson moments product correlation coefficient and simple linear regression analysis method were used to analyze the data of the research. The results of the research showed that the social independence skills of children are a significant explanatory of their readiness to school.
\end{abstract}

Keywords: Social independence, school readiness, pre-school education 


\section{Giriş}

Çocuk doğduğu andan itibaran sosyalleşmeye başlar ve okul öncesi dönem boyunca gerek ailesinden gerekse diğer yetişkinlerden sosyalleşme konusunda destek alır. Çevrenin bu konuda iyi bir rol model oluşturması çocuğun sosyal gelişimine ve sosyalleşmesine olumlu katkı sağlar. Okul öncesi eğitim kurumları çocuğun aile ortamından sonra dahil olduğu önemli bir sosyal ortamdır. Okul öncesi eğitim ortamında çocuğun içinde bulunduğu sosyal çevre, çocuğun sosyal ve duygusal gelişimini destekleyebilir. Özellikle çocuğun oyun ortamında akranlarıyla ve sınıf ortamında öğretmeniyle etkileşimleri kendine güven, kendini ifade etme ve sosyal bağımsızlık gibi sosyal becerilerinin gelişimine katkı sağlayabilir (Durualp, 2009). Ancak okul öncesi eğitimin çocuğun sosyalleşmesine olumlu katkıda bulunabilmesi için bu yeni girdiği sosyal ortamın çocuklar için uygun hale getirilmesi gereklidir.

Birçok çocuk okul ortamına girdiğinde evde kabul gören bazı davranışlarının, okuldaki sosyal sistem içerisinde kabul görmediğini, okulda farklı biçimlerde davranılması gerektiğini keşfeder (Senemoğlu, 1994). Bu noktada okul ortamina sosyal uyum konusunda verilecek destekler ve model olma, rol oynama, pekiştirme gibi sosyal beceri öğretimi stratejileriyle çocuğun olumlu davranış geliştirmesi sağlanabilir. Böylece çocuğun girişimcilik, sosyal açıdan bağımsız bir birey olma, iletişim kurma, yardımlaşma gibi birçok sosyal beceriyi edinmesi mümkün olabilir. Sosyal gelişim için gerekli olan bu sosyal becerilerin erken dönemlerden itibaren desteklenmesinin önemli olduğu, desteklenmediği durumlarda çocuğun sosyal gelişim, duygusal gelişim ve akademik performans bakımından sorunlar yaşadığı araştırmacılar tarafından vurgulanan bir konudur (Avcioğlu, 2005; Durualp ve Aral, 2011; Gülay, 2010). Okul öncesi dönemde sosyal gelişim iletişim kurabilme, olumlu sosyal etkileşim, sosyal işbirliği ve sosyal bağımsızlık gibi birçok sosyal beceriyi içerir (Barnett ve Belfield, 2006).

Okul öncesi dönemde geliştirilmesi gereken önemli gelişimsel hedeflerden birisi de başka bireylerden çok fazla destek almadan ve başka bireylere bağımlı olmaksızın sosyal açıdan bağımsız bir biçimde toplumla etkileşim içerisine girebilmektir (Landry, Smith, Swank ve Miller-Loncar, 2000). Çocuğun sosyal bağımsızlık becerisi bağımsız bir biçimde çalışabilme, kendi haklarını savunabilme, sosyal ortamlarda gerekli durumlarda karşı tarafın isteklerine uyma, kendi fikrini savunma gibi bir takım becerileri içerir. Çocuğun 
sosyal açıdan bağımsız davranabilmesinde önemli olan faktörlerden birisi de kendisini güvende hissetmesi ve anneden ayrılma konusunda zorluk çekmemesidir. Bowlby'nin bağlanma kuramı göz önünde bulundurulduğunda çocuğun annesinden ayrılma ve bireyselleşme konusunda duygusal açıdan zorluk yaşamaması güvenli bağlanma geliştirmesi ile mümkündür (Bowlby, 1998). Duygusal gelişimi yetersiz olan, ilişkilerinde aşırı duyarlı, anneye bağımlı ve anneden ayrılma konusunda zorluk çeken çocukların sosyal açıdan bağımsız davranabilmeleri ve okuldaki öğrenme faaliyetine katılmaları çok güçtür (Unutkan, 2003). Araştırmacilar, çocukların sosyal ve duygusal gelişmişlik düzeylerinin okula uyum, okul hazırbulunuşluğu ve okul başarılarına olan etkilerine işaret etmişlerdir (Cooper ve Farran, 1991; Hansen, 2012).

Hazır bulunuşluk; bireyin bir öğrenmeyi kazanabilmesi için gerekli ön koşul davranışları edinmesi anlamına gelirken (Canbulat ve Kırıktaş, 2016), aynı zamanda herhangi bir etkinliği yapmaya, bilişsel, duyuşsal, sosyal ve psiko-motor bakımdan hazır olma olarak da tanımlanabilir (Başaran, 1994). Okul hazırbulunuşluğu ise çocuğun fiziksel, zihinsel ve sosyal anlamda okulun gerekliliklerini karşılamaya hazır olması demektir (Güler, 2001). Okul hazırbulunuşluğu kavramı, genelde okumayı öğrenmeye hazırlık anlamında kullanılsa da, çocukların sosyal gelişimi ve entelektüel gelişimleri de okul hazırbulunuşluğu kavramı içerisinde düşünülmelidir (Unutkan, 2003). Hazır bulunuşluk ile ilgili çeşitli araştırmacılar çok sayıda faktör sıralasa da Oktay (2004) hazırbulunuşlukta fiziksel, zihinsel, duygusal, sosyal ve çevresel faktörlerin önemine dikkat çekmektedir. Çocuğun okulun isteklerini karşılamaya ve özellikle okumayı öğrenmeye hazır olması çok yönlü ve karmaşık bir olaydır. Araştırmacılar çocukların okul öncesi eğitim almalarının, bu eğitim sırasında sınıfa katılım, gruba katılım, işbirliği yapabilme becerilerinin ilköğretime hazırlık için ön şartlar olduğuna değinmektedir (Ladd, Birch ve Buhs, 1999; Robinson, 2009). Katz (1991) da, çocukların ilkokula hazırlığı kapsamında sosyal ve entelektüel açıdan okula hazır bulunuşluğun öğretmenler ve aileler tarafından dikkate alınması gereken önemli noktalardan biri olduğunu belirtmektedir (Akt. Tunçeli ve Akman, 2014). Bu nedenle araştırmada çocukların sosyal becerilerinden biri olan sosyal bağımsızlık düzeylerinin okula hazır olma durumlarını yordama durumu incelenmeye çalışılmıştır. Araştırmanın sosyal bağımsızlık ile okul hazırbulunuşluğu arasındaki ilişkiye dair ortaya koyduğu sonuçların mevcut durumu ortaya koyarak okula hazırbulunuşluğun sağlanması konusunda geliştirilecek erken müdahale 
programlarına önemli bir katkı sağlayacağı düşünülmektedir. Araştırma sonucunda geliştirilecek önerilerin alanda çalışan öğretmen ve anne babalara katkı sağlayacağı umulmakta, araştırmanın bu bakımdan da önem arz ettiği düşünülmektedir. Ayrıca alan yazında okula hazırbulunuşluk ile ilgili var olan araştırmalar incelendiğinde; arkadaş, aile, öğretmen, cinsiyet, sosyo ekonomik ve sosyo kültürel etkenler, okul öncesi eğitim alma (Esaspehlivan 2006; Gonca, 2004; Magnuson ve McGroder 2002; Thomas, 2008; Unutkan, 2003) gibi farklı değişkenlerin okula hazırbulunuşluğa etkilerinin incelendiği dikkat çekmiştir. Ancak sosyal gelişimle ilgili konuların okula hazırbulunuşlukla ilişkisinin sınırlı sayıda çalışıldığı görülmüştür. Mevcut araştırmalarda Tunçeli ve Akman (2014), Storch (2007), Cuskelly (2004) sosyal becerilerin, Ramey ve Ramey (2004) tüm gelişim alanlarını destekleyici erken müdehale programinin, Santo (2006) sosyal yeteneklerin, Parker ve ark. (1999) ebeveyn çocuk ilişkisinin ve olumlu ev ortamının, Thomas (2008) baba-çocuk ilişkisinin, Kılıç (2004) aile ile birlikte yaşamanın okula hazır oluşu olumlu etkilediğini belirtirken; Kahramanoğlu, Tiryaki ve Canpolat (2014) çekingen ve anneden kopamama davranışının okula hazır oluşu olumsuz etkilediğini belirtmişlerdir. Bu çalışmalarda görüldüğü üzere literatürde okula hazır oluş ile ilgili çalışmalar genel anlamda sosyal beceri, sosyal yetenek ve aile ile ilgili değişkenlere odaklanmıştır. Ancak sosyal becerilerin içerisinde spesifik olarak sosyal bağımsızlık değişkeninin okula hazırbulunuşluğu ile ilişkisinin ise ilk defa araştırıldığı görülmüştür. Bu nedenle araştırma konusunun alan yazında yer alan diğer araştırmalardan farklılık gösterdiği ve önemli olduğu düşünülmektedir.

Araştırmada okul öncesi çocukların sosyal bağımsızlık becerisi bağımsız değişken olarak, okul hazırbulunuşluğu ise bağımlı değişken olarak ele alınmıştır. Araştırmanın genel amacı okul öncesi çocukların sosyal bağımsızlık becerilerinin okula hazırbulunuşluk düzeylerini yordama durumunun belirlenmesidir. Bu genel amaç doğrultusunda aşağıdaki sorulara cevap aranmıştir.

1. Okul öncesi dönem çocuklarının sosyal bağımsızlık becerisi ve okul hazırbulunuşlukları arasında ilişki var mıdır?

2. Okul öncesi dönem çocuklarının sosyal bağımsızlık becerisi okul hazırbulunuşluklarının anlamlı bir yordayıcısı mıdır? 


\section{Yöntem}

\section{Araştırmanın Modeli}

$\mathrm{Bu}$ araştırma okul öncesi eğitime devam eden 60-72 aylık çocukların sosyal bağımsızlık becerilerinin okul hazırbulunuşluklarını yordama durumlarının incelenmesi amacıyla ilişkisel tarama modelinde yürütülmüştür. İlişkisel tarama modellerinde; iki ya da daha fazla sayıda değişken arasındaki birlikte değişimin varlı̆̆ı ve/veya derecesi belirlenmeye çalışılır (Karasar, 1999).

\section{Araştırma Grubu}

Araştırma 2018-2019 eğitim öğretim yılında Konya ilinde Milli Eğitim Bakanlığına bağlı ilköğretim okullarının anasınıflarına devam eden 60-72 aylar arasındaki çocuklar üzerinde yürütülmüştür. Araştırmanın örneklemini bu çocuklar arasından tesadüfi küme örnekleme yöntemiyle belirlenen 28 sinıftan 279 çocuk oluşturmuştur. Araştırmada Karatay bölgesinden 9, Meram bölgesinden 9, Selçuklu bölgesinden 10 anasınıfı random seçimle belirlenmiştir. $\mathrm{Bu}$ sinuflarda yer alan toplam 432 çocuğun velisine çocukların araştırmaya dahil edilmesi ile ilgili olarak bilgi verilerek araştırmaya katılım konusunda izin istenmiştir. Velileri tarafından izin verildiği şeklinde geri dönüş yapılan 279 çocuk için öğretmenler tarafından ölçme araçları doldurulmuştur. Süreçte geri dönüş alınamayan 153 velinin çocuğu araştırmaya dahil edilmemiştir. Araştırmaya katılan çocukların yaş ortalaması 63.4 (sd=1.84) aydır. Çocukların 134'ü kız, 145'i erkektir.

\section{Veri Toplama Araçları}

Anaokulu ve Anasınıf Davranış Ölçeği (Preschool and Kindergarten Behaviour Scale (PKBS-2): Okul öncesi dönem çocuklarının sosyal beceri ve problem davranışlarını ölçmek amacıyla 1994 yılında Kenneth W. Merril tarafından geliştirilmiş 2003 yılında tekrar revize edilmiştir. Ölçeğin Türkçe uyarlama geçerlik güvenilirlik çalışması Şahin Seçer, Çeliköz, Koçyiğit, Seçer ve Kayılı (2009) tarafından yapılmıştır. Ölçek Sosyal Beceri ve Problem Davranış Ölçekleri olmak üzere iki bağımsız ölçekten oluşmaktadır. Bu araştırmada 
ölçme aracının B Sosyal Beceri Formunun Sosyal Bağımsızlık Becerisi Alt ölçeği kullanılmıştır. Sosyal bağımsızlık becerisi alt boyutu okul öncesi dönem çocuklarının bakımını üstlenmiş kişilerden ya da ailesinden zorluk çıkarmadan ayrılabilmesi ve kendine güven duyarak akranları ile etkileşimde bulunabilmesi gibi becerilerini değerlendirmektedir. Bu ölçek, araştırmaya dahil edilen her bir çocuk için, öğretmeni tarafından doldurulmuştur. Sosyal bağımsızlık alt ölçeği 11 maddeden oluşmakta olup ölçekten alınabilecek en düşük puan 11, en yükssek puan ise 55'dir. Ölçekten alınabilecek yüksek puanlar çocuğun sosyal ortamlarda kendi başına her hangi bir zorlanma olmaksızın etkileşim kurabilme ve sürdürebilme becerisinin gelişmiş olduğu şeklinde yorumlanmaktadır. Ölçek beşli likert değerlendirmeyi (1-5) içermektedir. Öğretmenler ölçekte yer alan her bir maddeye ilişkin; "hiç katılmıyorum", "katılmıyorum", "kararsızım", "katıllyorum" ve "tamamen katıllyorum" kategorilerinden birisini işaretleyerek belirtmişlerdir.

Ölçeğin Şahin Seçer ve arkadaşları (2009) tarafından yapılan geçerlik güvenirlik çalışmalarında yapı geçerliliğinin sağlanabilmesi için faktör analizi yapılmıştır. Ölçeğin sosyal beceriler boyutunda yer alan 3 faktörün toplam varyansı açıklama oranı \% 74.34, Cronbach Alfa Güvenirlik Katsayısı ise $.98^{\prime}$ dir. Sosyal bağımsızlık alt boyutunun Cronbach Alfa kat sayısı ise $.95^{\prime}$ dir. Bu çalışmada ölçeğin Cronbach alfa güvenirlik katsayısı tekrar hesaplanmış ve, 89 olarak saptanmıştır.

\section{Okul Öncesi Davranışsal ve Duygusal Dereceleme Ölçeği-OÖDDDÖ (Presc-} hool Behavioral and Emotional Rating Scale-PreBERS): Okul Öncesi Davranışsal ve Duygusal Dereceleme Ölçeği Okul öncesi çocukları davranışsal ve duygusal açıdan değerlendirmek amacıyla Epstein ve Synhorst (2009) tarafından geliştirilmiş bir ölçme aracıdır. Ölçeğin Türkçe'ye uyarlama, geçerlik ve güvenilirlik çalışmaları altı yaş çocukları üzerinde Öztürk Samur, Deniz, Durmuşoğlu Saltalı \& Arı (2009) tarafından yapılmıştır. Ölçek, duyguları düzenleme, okul hazırbulunuşluğu, sosyal güven ve aileye ait olma olmak üzere dört alt boyuttan oluşan bir ölçektir (Epstein \& Synhorst, 2009). Bu çalışma kapsamında ölçeğin okula hazırbulunuşluk alt boyutu kullanılmıştır. Okula hazır bulununuşluk alt boyutu, okul başarısı ile ilişkili temel öğrenme ve dil becerilerini temsil eden 13 madde içermektedir (örneğin, yönergeleri takip eder). Bu ölçek, araştırmaya dahil edilen her bir çocuk için, öğretmeni tarafın- 
dan doldurulmuştur. 4'lü likert değerlendirme (hiç uymuyor=0, biraz uyuyor=1, uyuyor=2, tamamen uyuyor=3) içeren ölçekten 0-39 arası puan alınabilmektedir. Ölçekten alınabilecek yüksek puanlar çocuğun okul hazırbulunşluğunun yüksek olduğu şeklinde yorumlanmaktadır. Ölçeğin Türkçe uyarlama geçerlik güvenirlik çalışmalarında okula hazırbulunuşluk altboyutu için Cronbach alfa katsayısı 0.96 olarak bulunmuştur. Bu çalışma kapsaminda yeniden hesaplanan Cronbach alfa katsayısı .91'dir.

\section{Verilerin Analizi}

Araştırma kapsamında okul öncesi çocuklarının sosyal bağımsızlık ve okula hazırbulunuşluk durumlarına ilişkin ölçme araçları her bir çocuk için öğretmenleri tarafından doldurulmuştur. Verilerin istatistiksel değerlendirilmesinde IBM İstatistik SPSS 22.0 paket programı kullanılmıştır. Araştırmanın verilerinin çözümlenmesinde Pearson momentler çarpım korelasyon katsayısı ve basit doğrusal regresyon analizi yöntemi kullanılmıştır. Araştırmada önem düzeyi .05 olarak kabul edilmiştir.

\section{Bulgular}

Tablo 1'de çocukların sosyal bağımsızlık puanları ve okul hazırbulunuşluğu puanlarına ilişkin betimleyici istatistik bulguları görülmektedir.

Tablo 1. Araştırma değişkenlerine ilişkin betimsel istatistikler

\begin{tabular}{llllll}
\hline & $\mathbf{N}$ & $\mathbf{X}$ & Ss & Minimum & Maximum \\
\hline Sosyal bağımsızlık & 279 & 21.05 & 7.30 & 13.00 & 43.00 \\
\hline Okula hazırbulunuşluk & 279 & 18.99 & 8.45 & 11.00 & 38.00 \\
\hline
\end{tabular}

Tablo 1 incelendiğinde araştırmaya katılan çocukların sosyal bağımsızlık puan ortalamalarının 21.05, okula hazırbulunuşluk puan ortalamalarının 18.99 olduğu görülmektedir.

Araştırmanın birinci sorusuna yanıt aramak üzere yapılan okul öncesi dönem çocukların sosyal bağımsızlık puanları ile okula hazırbulunuşluk puanları arasındaki ilişki düzeyinin belirlenmesine ilişkin pearson momentler çarpım korelasyon katsayısı analizi sonuçları Tablo 2'de verilmiştir. 
Tablo 2. Sosyal bağımsızlık ile okula hazırbulunuşluk değişkenleri arasındaki ilişkiye ait bulgular

\begin{tabular}{ll}
\hline & Okula hazırbulunuşluk \\
\hline Sosyal bağımsızlık & $.84^{* *}$ \\
\hline${ }^{* *} \mathrm{P}<.01$ &
\end{tabular}

Tablo 2 incelendiğinde araştırmanın değişkenleri arasındaki ilişkiyi belirlemek üzere yapılan korelasyon analizi sonucunda; 60-72 aylık çocukların sosyal bağımsızlık becerileri ile okul hazırbulunuşlukları arasında $\mathrm{p}<.01$ düzeyinde pozitif yönlü ( $r=.84$ ) yüksek düzeyde bir ilişki olduğu görülmektedir.

Korelasyon analizi sonucunda ortaya çıkan bu ilişki doğrultusunda araştırmanın ikinci alt problemi olan okul öncesi dönem çocukların sosyal bağımsızlık becerilerinin okula hazırbulunuşluk durumlarını yordama durumları incelenmiştir. Bu sorunun cevabı basit doğrusal regresyon analizi yöntemi kullanılarak belirlenmeye çalışılmış ve bulgular Tablo 3'de sunulmuştur.

Tablo 3. Okula hazırbulunuşluğun sosyal bağımsızlık tarafından yordanmasına ilişkin basit doğrusal regresyon analizi bulgularn

\begin{tabular}{lllllllll}
\hline & $\boldsymbol{R}$ & $\boldsymbol{R}^{2}$ & $\boldsymbol{R}^{2}$ ch & $\boldsymbol{F}$ & $\boldsymbol{D} f$ & Beta & $\boldsymbol{\beta}$ & $\boldsymbol{p}$ \\
\hline Sosyal bağımsızlık & .84 & .70 & .70 & 416,770 & $1 / 277$ & & & \\
\hline & & & & & .97 & .84 &, $000^{* *}$ \\
\hline
\end{tabular}

$* * \mathrm{P}<.01$

Tablo 3 incelendiğinde 60-72 aylık çocukların sosyal bağımsızlık becerileri okula hazırbulunuşluk düzeylerini anlamlı düzeyde açıkladığı görülmekte$\operatorname{dir}\left(\mathrm{R}=.84, \mathrm{R}^{2}=.70, \mathrm{~F}_{(1 / 277)}=416,770, \mathrm{p}<.01\right)$. Sosyal bağımsızlık becerisinin, okula hazırbulunuşluk puanlarındaki toplam varyansının \%70'ini açıkladığı saptanmiştır.

\section{Tartışma ve Sonuç}

Araştırmadan elde edilen bulgular ışığında 60-72 aylık çocuklarda sosyal bağımsızlığın okula hazırbulunuşluk durumunun anlamlı bir yordayıcısı olduğu görülmüştür. Alan yazın incelendiğinde de benzer araştırma sonuçlarının olduğu görülmektedir. Tunçeli ve Akman (2014), çalışmalarında 6 yaş çocuklarının sosyal becerilerinin okula hazır oluş ile ilişkilerini araştırmışlar- 
dır. Araştırmaları sonucunda çocukların sosyal beceri düzeylerinin okul olgunluğu düzeylerini pozitif yönde anlamlı yordadığını bulmuşlardır. Ramey ve Ramey (2004), erken öğrenme ve okula hazırbulunuşluk üzerine yaptıkları çalışmalarında okul öncesi çocuklarına sosyal gelişimi de dâhil olmak üzere tüm gelişim alanlarını destekleyici bir program uygulamışlar ve bu programın çocukları okula hazır hale getirdiğini saptamışlardır. Bracken, Stacey Storch (2007), çalışmalarında sosyal beceri ve davranış sorunlarının çocukların okula hazır oluşlarına etkisini incelemişlerdir. Okul öncesi dönem boyunca sosyal becerileri gelişen çocukların okula hazırbulunuşluk düzeylerinin de geliştiğini saptamışlardır. Bu sonuçlar araştırma bulgularıyla paralellik göstermektedir.

Ladd, Birch ve Buhs (1999) çocukların okul öncesi eğitim alma durumlarının sınıfa katılma, birlikte çalışabilme ve bağımsız olabilme yeteneklerini desteklediğini ve bu becerilerin ilköğretime hazırlık için ön şartlar olduğunu söylemektedir. Araştırma sonucunda elde edilen sosyal bağımsızlığın okula hazırbulunuşluğun yordayıcısı olduğu sonucu bu literatür bilgisiyle uyumludur. Ayrıca literatürde ailesi ile arasındaki yakın ilişki ve bağlanma kalitesi yüksek olan öğrencilerin sosyal bağımsızlık becerilerinin yüksek olduğu şeklinde bilgiler yer almaktadır (Maccoby ve Martin, 1983). Okul ortamında kendisini güvende hisseden, aileden ayrilma konusunda problem yaşamayan, kararlarını kendisi alabilen, sosyal açıdan kimseye bağımlı olmayan çocukların sınıfta derslere dikkatini verebilme ve öğrenmeye motive olma konusunda avantajlı oldukları düşünülmektedir (Hoffman, 1983). Bunun yanı sıra çocukların bağımsızlık, kendini kontrol ve işbirliği yapabilme becerilerinin öğrenme ortamına pozitif yaklaşma ve sınıf içi öğrenme aktivitelerine katılma anlamında olumlu katkıları olduğu şeklinde literatürde bilgiler yer almaktadır (Cooper ve Farran, 1991; Robinson, 2009). Araştırma sonuçlarımizda bu bilgileri destekler niteliktedir.

Alan yazında okula hazır oluşu sosyal gelişim ve sosyal beceriler çerçevesinde aile ve öğretmen görüsslerine göre inceleyen araştırmalar da mevcuttur. Kahramanoğlu, Tiryaki ve Canpolat (2014) yaptıkları çalışmada çocukların okula hazır oluşlarını öğretmen görüşleri çerçevesinde incelemişlerdir. Çalışmaları sonucunda öğretmenlere göre anneden kopamama ve çekingen davranışların okula hazır oluşu olumsuz etkilediğini belirtmişlerdir. Unutkan (2003) anneye bağımlı ve anneden ayrılma konusunda sıkıntı yaşayan çocukların sosyal açıdan bağımsız davranamadıklarını belirtmektedir. Santo 
(2006), okul öncesi eğitim öğretmenlerinin okula hazır oluş ile ilgili görüşlerini incelemiş ve öğretmenlerin büyük bir çoğunluğunun, çocuğun sosyal yeteneklerinin da okula başlangıç için önemli olduğunu düşündüklerini belirtmiştir. McBryde, Ziviani ve Cuskelly (2004) ise çalışmalarında hem öğretmenlerin hem de ailelerin ilkokula başlama sürecinde iyi geliştirilen sosyal becerilerin etkili olduğunu düşündüğünü saptamıştır. Bütün bu sonuçlar da bu araştırmanın bulguları ile uyumludur.

$\mathrm{Bu}$ araştırmanın sonuçlarına göre okula hazırbulunuşluğun \%70'lik kısmının sosyal bağımsızlık değişkeni ile açıklandığı görülmektedir. Okula hazırbulunuşluğun açılanmayan \%30'luk kısmının ise başka değişkenlerden etkilenmiş olabileceği düşünülmektedir. Alan yazında çocukların okula hazırbulunuşluğu üzerinde çocuğun çevresiyle dolaylı ya da direk etkileşiminin, arkadaşları, ailesi ve öğretmeni ile olan ilişkisinin, akademik yeteneklerinin, bilişsel, dil, sosyal ve duygusal becerilerinin etkili olabileceği belirtilmektedir (Thomas, 2008). Parker ve ark. (1999), yaptıkları çalışmada ebeveyn çocuk ilişkisinin ve olumlu ev ortamının çocukların okula hazır oluş düzeylerini olumlu etkilediğini ve hatta bu olumlu ilişki sayesinde çocukların sınıf ortamında daha bağımsız davrandıkların belirtmişlerdir. Thomas (2008), yaptığı çalışmada baba-çocuk etkileşimin çocuklarda okula hazır oluşta belirleyici olduğunu, babasız olarak büyüyen çocukların okula hazır oluş düzeylerinin diğer çocuklara göre daha düşük seviyede olduğunu vurgulamıştır. Kılıç (2004) tarafından yapılan çalışmada ailesiyle birlikte yaşayan çocukların, çocuk yuvasında kalan çocuklara oranla okula daha hazır başladıkları sonucununa ulaşılmıştır. Esaspehlivan (2006) ve Unutkan (2003), okul öncesi eğitim alan çocukların okul öncesi eğitim alamayan çocuklara göre okula daha üst düzeyde hazır olarak başladıklarını belirtirken, Unutkan (2003) yaptığı çalışma ile ebeveynlerin eğitim düzeyleri ve mesleklerinin de çocuklara yaşantı zenginliği sağlaması bakımından çocukların okula hazır bulunuşluklarına katkı sağladığını belirtmiştir. Gonca (2004), çalışmasında çocukların okul hazır bulunuşluklarının sosyoekonomik ve kültürel düzeye göre farkl1laştığını sosyoekonomik ve kültürel düzeyi yüksek çocukların okul hazırbulunuşluğunun da yüksek olduğunu bulmuştur. Magnuson ve McGroder (2002), annenin eğitim düzeyinin artmasının çocukların okula hazır bulunuşluğu ile pozitif yönlü ve akademik problemler ile negatif yönlü ilişkisinin olduğu saptamışlardır. Araştırma sonuçlarına göre okula hazırbulunuşluğun 
açıklanamayan \%30'luk kısmının bu gibi değişkenlerden etkilenmiş olabileceği düşünülmektedir.

Bu araştırmanın sonuçları okul öncesi dönem çocuklarının sosyal bağımsızlık becerilerinin okul hazırbulunuşlukları ile ilişkili olduğunu ve sosyal bağımsızlık becerisinin okul hazırbulnuşluğunun anlamlı bir yordayıcısı olduğunu göstermiştir. Araştırma sonuçlarına dayalı olarak gelecek araştırmalar ve uygulamaya yönelik olarak aşağıdaki öneriler geliştirilmiştir.

Çocukların okul hazırbulunuşluklarını olumlu yönde etkilemek için aile içerisinde sosyal bağımsızlıklarını destekleyici uygulamalar yapılabilir. Gerek aile içerisinde ebeveyn tutumlarında çocuğun bağımsızlığının desteklenmesi, gerek toplumsal olarak sosyal bağımsızlığın olumlu bir özellik olarak kabulünün sağlanması, gerekse oyun ortamlarında bağımsızlığı özendirici akran ilişkileri çocuğun sosyal bağımsızlık becerisinin gelişimine katkı sağlayabilir. Bunun içinde aile ve topluma yönelik eğitimler düzenlenebilir. Oyun grupları kurularak akran etkileşimi firsatları sunulabilir. Bundan sonra yapılacak araştırmalarda okul hazırbulunuşluğunun farklı sosyal becerilerle ilişkileri araştırmacılar tarafından ele alınabilir. 


\title{
EXTENDED ABSTRACT
}

\section{Social Independence as a Predictor of School Readiness of Preschool Children}

\author{
Filiz Erbay - Neslihan Durmuşoğlu Saltalı \\ Near East University, Ordu University
}

One of the general aims of pre-school education is to prepare children for school. Preparing the child for school is a multifaceted and complex event that concerns all areas of development. Readiness levels have been widely taken into account in determining whether a child is ready for school in recent years. Readiness; While it means acquiring the necessary precondition behaviors for an individual to gain a learning (Canbulat and Kırıktaş, 2016), it can also be defined as being ready to do any activity in terms of cognitive, affective, social and psycho-motor aspects (Başaran, 1994). School readiness means that the child is ready to meet the requirements of the school in terms of physical, mental and social aspects (Güler, 2001). Researchers point out that pre-school education of children, participation in the class during this education, participation in the group, and ability to cooperate are prerequisites for preparation for primary education (Ladd, Birch, and Buhs, 1999; Robinson, 2009). Katz (1991) states that social and intellectual school readiness is one of the important points that should be taken into consideration by teachers and families within the scope of preparing children for primary school (cited in Tunçeli and Akman, 2014). For this reason, the predictive status of social independence levels, which is one of the social skills of children, for school readiness has been investigated. One of the variables that can affect children's school readiness in this period is social development and competencies in social skills. It is an issue emphasized by researchers that it is important to support these social skills, which are necessary for social development, from the early stages, and that the child has problems in terms of social development, emotional development and academic performance when not supported (Avcioğlu, 2005; Durualp and Aral, 2011; Gülay, 2010). In this context, it was aimed to determine the predictive status of preschool children's social independence skills on school readiness. 
This research was conducted in relational scanning model from cross sectional study. The research was conducted on children between the ages of 60 and 72 who attend kindergartens of primary schools affiliated to the Ministry of National Education in Konya in the 2018-2019 academic year. The sample of the study consisted of 279 children from 28 classes determined by random cluster sampling method. In the research, social independence sub-dimension of Kindergarten and Kindergarten Behavior Scale was used to determine the social independence levels of children. It was developed by Kenneth W. Merril in 1994 to measure social skills and problem behaviors of pre-scale children and was revised in 2003. The Turkish adaptation and reliability study of the scale was conducted by Şahin Seçer, Çeliköz, Koçyiğit, Seçer, and Kayll (2009). Social independence sub-dimension consists of 11 items, scores between 11-55 can be obtained from the scale. In this study, the Cronbach alpha reliability coefficient of the scale was re-calculated and it was found as 89. Preschool Behavioral and Emotional Rating Scale was used to determine children's school readiness levels in the study. Preschool Behavioral and Emotional Rating Scale It is a measurement tool developed by Epstein and Synhorst (2009) to evaluate preschool children behaviorally and emotionally. The adaptation, validity and reliability studies of the scale into Turkish were performed by Öztürk Samur, Deniz, Durmuşoğlu Saltalı \& Ar1 (2009) on children aged six years. In this study, the recalculated Cronbach alpha coefficient of the scale is .91. Scores between 0-39 can be obtained from the scale.

Within the scope of the research, measurement tools regarding the social independence and school readiness of preschool children were filled in by their teachers for each child. IBM Statistics SPSS 22.0 package program was used for the statistical evaluation of the data. Pearson moments product correlation coefficient and simple linear regression analysis method were used to analyze the data of the study. The significance level in the study was accepted as .05 .

The social independence mean score of the children participating in the study was 21.05 , and their school readiness mean score was 18.99 . As a result of the correlation analysis made to determine the relationship between the variables of the research; It has been observed that there is a high level positive correlation $(\mathrm{r}=.84)$ at $\mathrm{p}<.01$ level between social independence skills and school readiness of 60-72 month-old children. In addition, it was determined that the social independence skills of 60-72 month-old children significantly 
explained their school readiness level $(\mathrm{R}=.84, \mathrm{R} 2=.70, \mathrm{~F}(1 / 277)=416,770, \mathrm{p}$ $<.01)$.

The results of this study showed that preschool children's social independence skills are associated with school readiness, and social independence skill is a significant predictor of school readiness. Ladd, Birch, and Buhs (1999) state that children's pre-school education supports their ability to participate in the classroom, work together and be independent, and these skills are prerequisites for preparation for primary education. Similar studies are also found in the literature. In the results of this study, a relationship was found between the social skills of preschool children and their school readiness (Ramey and Ramey, 2004; Stacey Storch, 2007; Tunçeli and Akman, 2014).

According to the results of this research, it is seen that $70 \%$ of school readiness is explained by the social independence variable. It is thought that the undisclosed $30 \%$ of school readiness may have been affected by other variables. While Magnuson and McGroder (2002) stated that the increase in the education level of the mother is positively associated with children's school readiness, Parker et al. (1999) emphasized in their study that parent-child relationship and a positive home environment positively affect children's school readiness.

In order to positively affect the school readiness of children, practices that support their social independence can be made within the family. Supporting the independence of the child in parental attitudes within the family, ensuring social independence as a positive feature, and peer relationships that encourage independence in play environments can contribute to the development of the child's social independence skill. For this, trainings for family and society can be organized. Peer interaction opportunities can be offered by establishing playgroups. In future research, the relationship between school readiness and different social skills can be discussed by researchers.

\section{Kaynakça / References}

Avcıŏlu, H. (2005). Etkinliklerle sosyal beceri öğretimi. Ankara; Kök Yayınclık.

Barnett, W. S., ve Belfield, C. R. (2006). Early childhood development and social mobility. The Future of Children, 16(2), 73-98.

Başaran, İ. E. (1994). Eğitim psikolojisi (5. Baskı). Ankara: Gül Yayınevi.

Bracken, S. S. ve Fischel, J. (2007). Relationships between social skills, behavioral problems, and school readiness for head start children. NHSA Dialog, 10(2), 109-126. 
Bowlby, J. (1998). Attachment and Loss, Vol. II. Seperation, anxiety and anger, Australia, Pimlico.

Canbulat, T., ve Kırıktaş, H. (2016). İkkokula Hazır Bulunuşluk Ölçeği'nin geliştirilmesi: geçerlik ve güvenilirlik çalışması. Academia Eğitim Araştırmalan Dergisi, 1(1), 2635.

Cooper, D. H., ve Farran, D. C. (1991). The Cooper-Farran Behavioral Rating Scales. Brandon, VT: Clinical Psychology Publishing Co., Inc.

Durualp, E. ve Aral, N. (2011). Oyun temelli sosyal beceri eğitimi. Ankara: Vize Basın Yayın.

Durualp, E. (2009). Anasmifina devan eden çocuklarm sosyal becerilerine oyun temelli sosyal beceri eğitiminin etkisinin incelenmesi: Çankırı örneği. Doktora tezi, Ankara Üniversitesi, Ankara.

Esaspehlivan, M. (2006). Okul öncesi eğitim kurumuna gitmiş ve gitmemiş 78 ve 68 aylk çocuklarnn okula hazır bulunuşluklarmmn karşlaştırlması. Yüksek Lisans Tezi. Marmara Üniversitesi, Eğitim Bilimleri Enstitüsü, İstanbul.

Gonca, H. (2004). Ankara il merkezinde farkh sosyo-ekonomik ve kültürel ortamlarda yetişen ve ilköğretim okuluna yeni başlayan çocuklarn okul olgunluğunun incelenmesi. Yüksek Lisans Tezi. Hacettepe Üniversitesi, Sağlık Bilimleri Enstitüsü, Ankara.

Gülay, H. (2010). Okul öncesi dönemde akran ilişkileri. Ankara: Pegem A Yayıncllk.

Güler, D. S. (2001). 4-5 ve 6 yaş okul öncesi eğitim programlarmm değerlendirilmesi. Doktora Tezi. Ankara Üniversitesi Sosyal Bilimler Enstitüsü, Ankara

Hansen, J. A. (2012). Parental perceptions of social emotional skills for kindergarten readiness. Master Thesis, Southwest Minnesota State University, Education Department, Marshall, Minnesota.

Hoffman, L. (1984). Work, family, and the socialization of the child. In R. Parke (Ed.), Review of child development research (Vol. 7, p. 223-282). Chicago: University of Chicago Press.

Kahramanoğlu, R., Tiryaki E. N. ve Canpolat, M. (2014). İlkokula yeni başlayan 60-66 ay grubu öğrencilerin okula hazır oluşları üzerine inceleme. K. Ü. Kastamonu Eğitim Dergisi, 23(3), 1065-1080.

Kılıç, G. Ü. (2004). Ailesiyle birlikte yaşayan ve çocuk yuvasinda kalan çocuklarn görsel algılama davramışı ile okul olgunluğu arasindaki ilişkinin incelenmesi. Yüksek Lisans Tezi. Ankara Üniversitesi, Fen Bilimleri Enstitüsü, Ankara.

Ladd, G. W., Birch, S. H. ve Buhs, E. (1999). Children's social and scholastic lives in kindergarten: related spheres of influence? Child Development, 70(6), 1373-1400. 
Landry, S. H., Smith, K. E., Swank, P. R., ve Miller-Loncar, C. L. (2000). Early maternal and child influences on children's later independent cognitive and social functioning. Child Development, 71(2): 358-375.

Maccoby, E. E. ve Martin, J. A. (1983). Socialization in the context of the family: Parentchild interaction. In P. H. Mussen (Series Ed.) \& E. M. Hetherington (Vol. Ed.), Handbook of child psychology: Vol. 4. Socialization, personality, and social development (4th ed., p. 1-101). New York: Wiley.

Magnuson K. A. ve McGroder, S. M. (2002). The effect of increasing welfare mothers' education on their children's young children's academic problems and school readiness. JCPR Working Paper, 1-31.

McBryde, C., Ziviani, J., ve Cuskelly, M. (2004), School readiness and factors that influence decision making. Occupational Therapy International, 11(4), 193-208.

Oktay, A. (2004). Yaşamın sihirli yılları. İstanbul: Epsilon Yayınları.

Öztürk Samur, A., Deniz, M. E., Durmuşoğlu Saltalı, N. ve Arı, R. (2009). Altı Yaş Çocukları İçin Davranışsal ve Duygusal Değerlendirme Ölçeği: geçerlik güvenirlik çalışması, Uluslararası Katılımlı II. Çocuk Gelişimi ve Eğitimi Kongresi, Hacettepe Üniversitesi, 7-9 Ekim 2009, Ankara. 611-618.

Parker, F. L., Boak, A. Y., Griffin, K. W., Ripple, C. ve Peay, L. (1999). Parent-child relationship, home learning environment, and school readiness. School Psychology Review, 28(3), 413-425.

Ramey, C. T. ve Ramey, S. L. (2004). Early learning and school readiness: can early intervention make a difference? Merrill-Palmer Quarterly, 50(4), 471-491.

Robinson, C. D. (2009). Preschool to kindergarten: the role of preschool social competence in the transition to kindergarten. Master thesis, Purdue University.

Santo, A. (2006). School readiness: perceptions of early childhood educators, parents and preschool children. Doctoral dissertation, University of Toronto, Department of Human Development and Applied Psychology, Toronto.

Senemoğlu, N. (1994). Okul öncesi eğitim programı hangi yeterlikleri kazandırmalıdır? Hacettepe Üniversitesi Eğitim Fakültesi Dergisi, 10, 21-30.

Şahin Secer, Z., Çeliköz, N., Koçyiğit, S., Secer, F. ve Kayıll, G. (2009). Social skills and problem behaviours of children with different cognitive styles who attend preschool education. Procedia Social and Behavioral Sciences, 1, 1554-1560.

Thomas, D. (2008). Parental Involvement in Pre-School Readiness. Master thesis. Humboldt State University, ABD

Tuçeli, H. İ. ve Akman. B. (2014). Anaokullarına devam eden 6 yaş çocuklarının sosyal becerilerinin okul olgunluklarına etkilerinin incelenmesi. Eğitim ve Öğretim Araştırmaları Dergisi, 3(4), 333-341. 
Okul Öncesi Dönem Çocuklarının Okul Hazırbulunuşluklarının Yordayıcısı Olarak Sosyal Bağımsızlık

Unutkan, Ö. P. (2003). Marmara Ilköğretime Hazır Oluş Ölçeğinin geliştirilmesi ve standardizasyonu. Doktora Tezi. Marmara Üniversitesi, Eğitim Bilimleri Enstitüsü, İstanbul.

Kaynakça Bilgisi / Citation Information

Erbay, F. ve Durmuşoğlu Saltalı, N. (2020). Okul öncesi dönem çocuklarının okul hazırbulunuşluklarının yordayıcısı olarak sosyal bağımsızlık OPUS-Uluslararası Toplum Araştırmaları Dergisi, 16(31), 41384155. DOI: $10.26466 /$ opus.681864 